\title{
STUDI KASUS POLA MANAJEMEN PONDOK PESANTREN AL-RAISIYAH DI KOTA MATARAM
}

\author{
Nurul Yakin \\ (Fakultas Ilmu Tarbiyah dan Keguruan IAIN Mataram \\ E-mail: nurul311264@yahoo.com)
}

Abstract: Pesantren is the oldest Islamic educational institution in Indonesia. Due to its strongly established existence and dyanamics up to present times, it has become an interesting topic of research. This article attempts to examine one of the traditional pesantrens in Mataram, namely Al-Raisiyah. Using case study method, it focuses the pesantren's management. This study argues that the pesantren does employ a single management but a multi-management system. The pesantren combines the official curriculum of education unit level with special cirruculum of pesantren. Although the pesantren does not recruit teachers openly so the recruitment is not competitive, it adopts an open and modern management regarding student affairs, infrastructure and financial resources. The pesantren's school committee, which is very traditional in its vision and orientation, tends to emphasize a model of traditional pattern of social communication and relations.

Abstraks: Pondok pesantren merupakan model pendidikan Islam pertama di Indonesia yang tetap eksis hingga kini, dan karenanya tetap menarik untuk dikaji. Tulisan ini mengupas pola penerapan manajemen Pondok Pesantren Al-Raisiyah Mataram. Dengan pendekatan studi kasus penulis menemukan bahwa: (1) Pola manajemen kurikulum di Pondok Pesantren Al-Raisiyah adalah kurikulum perpaduan antara Kurukulum KTSP yang bersifat formal dengan Kurikulum Takhassus sehingga menghasilkan suatu bentuk KTSP Pondok. (2) Manajemen pendidik dan tenaga kependidikan menerapkan pola tertutup, di mana proses rekrutmen dilaksanakan tanpa publikasi dan diprioritaskan bagi kalangan tertentu. (3) Manajemen kesiswaan, manajemen sarana dan prasarana, serta manajemen pembiayaan menerapkan pola terbuka dan modern dengan memerhatikan penerapan fungsi-fungsi manajemen. (4) Pola manajemen bubungan masyarakat cenderung menerapkan "pola tradisional" di mana komunikasi madrasah dengan orang tua atau masyarakat masih didominasi oleh keberadaan komite madrasah.

Keywords: Manajemen, Pesantren, Pondok Pesantren Al-Raisiyah. 
PESANTREN merupakan sistem pendidikan tertua saat ini jika dibandingkan dengan lembaga pendidikan yang pernah muncul di Indonesia dan sejak lama sudah dianggap sebagai produk budaya Indonesia yang indigenous (berkarakter khas). Lembaga pendidikan Islam ini mulai dikenal setelah masuknya Islam ke Indonesia pada abad VII, akan tetapi keberadaan dan perkembangannya baru popular sekitar abad XVI. Sejak saat itu telah banyak dijumpai lembaga yang bernama pesantren yang mengajarkan berbagai kitab Islam klasik dalam bidang fiqh, aqidah, tasawuf dan menjadi pusat penyiaran Islam. ${ }^{1}$

Kelebihan pesantren adalah terletak pada kemampuannya menciptakan sebuah sikap hidup universal yang merata yang diikuti oleh semua santri, sehingga lebih mandiri dan tidak bergantung pada siapa dan lembaga masyarakat apapun. ${ }^{2}$ Perkembangan dan kelebihan pesantren erat kaitannya dengan sistem manajemen yang dikembangkan.

Manajemen merupakan suatu konsep yang mengkaji keterkaitan dimensi perilaku, komponen sistem dalam kaitannya dengan perubahan dan pengembangan organisasi. Tuntutan perubahan dan pengembangan yang muncul sebagai akibat tuntutan lingkungan internal dan eksternal, membawa implikasi terhadap perubahan perilaku kelompok dan wadahnya. ${ }^{3}$ Perubahan mempunyai tujuan yang sifatnya penyesuaian diri dengan lingkungan agar tujuan organisasi sesuai dengan kebutuhan atau tuntutan masyarakat. Kunci dari perubahan di organisasi pondok pesantren adalah orang yang memimpin, yaitu bagaimana ia menjalankan masa kepemimpinannya.

Selain faktor kepemimpinan kyai atau tuan guru, perkembangan pondok pesantren tentunya juga tidak luput dari penerapan fungsi-fungsi manajemen yang lain. Manajemen adalah seperangkat aktivitas yang dirancang untuk mencapai sebuah tujuan organisasi melalui pemanfaatan sumber daya yang

${ }^{1}$ Zamakhsyari Dhofier, Tradisi Pesantren Studi Tentang Pandangan Hidup Kiyai (Jakarta: LP3ES, 2011), 34.

2Abdurrahman Wahid, Bunga Rampai Pesantren (Jakarta: Dharma Bhakti, 1999), 74. 39.

${ }^{3}$ Nanang Fattah, Landasan Manajemen Pendidikan (Bandung: RR, 2001), 
tersedia secara efektif dan efisien. ${ }^{4}$ Efektif artinya hasil tercapai sesuai dengan keinginan organisasi. Efisien artinya pekerjaan dapat diselesaikan dengan menggunakan sumber daya aparatur seminimal mungkin.

Kemampuan pesantren untuk tetap bertahan dan bahkan eksistensi pendidikannya diakui sebagai bagian dari sistem pendidikan nasional tidak terlepas dari sistem manajemen pendidikan yang dikembangkan selama ini. Menurut Mastuhu, suatu sistem pendidikan (termasuk pondok pesantren) akan menentukan apakah lembaga pendidikan yang bersangkutan akan diminati atau tidak oleh khalayak. Suatu sistem pendidikan dikatakan mampu melayani tantangan zamannya apabila ia mampu merespons kebutuhan anak didik dan mengembangkan kemampuannya sesuai dengan kecenderungannya, merespons kemajuan ilmu dan teknologi, serta kebutuhan pembangunan nasional. Di samping itu, sistem pendidikan juga akan diminati oleh khalayak apabila ia mampu memberikan pedoman moral atau budi pekerti luhur sesuai dengan keyakinanya, mengembangkan keterampilan atau keahlian sehingga mereka mampu hidup hormat dan disegani dalam tata pergaulan bersama di masyarakat, mendatangkan manfaat, rasa aman, dan kepercayaan, serta harapan bagi masyarakatnya untuk mamajukan kehidupan bersama lahiriah-batiniah. ${ }^{5}$

Pondok Pesantren Al-Raisiyah berada di Sekarbela, suatu daerah yang cukup terkenal di kota Mataram. Sekarbela oleh khalayak dikenal karena tiga faktor utama. Pertama, daerah ini sejak masa silam dikenal dengan khazanah keagamaan yang menonjol di kota Mataram karena banyaknya tokoh agama (tuan guru) yang lahir dari daerah tersebut dan mengajarkan serta mengasuh warga masyarakat di tanah Sasak. Kedua, Sekarbela memiliki masjid tua bersejarah yang berada di tengah pemukiman padat penduduk, warisan penyebar agama terdahulu dan kini memiliki bangunan menara yang tinggi menyerupai menara masjid Nabawi. Masjid tersebut dulunya sering disebut dengan Mesigit Bengaq (masjid yang menakjubkan) namun kini

${ }^{4}$ Benjamin S. Bloom, Taxonomy of Educational Objectives (New York: Longman, Inc, 1981), 18-24.

${ }^{5}$ Mastuhu, Dinamika ..., 41. 
lebih akrab disebut dengan nama masjid Al-Raisiyah. Ketiga, Sekarbela dikenal sebagai daerah produsen atau penghasil kerajinan perhiasan berbahan baku emas, perak dengan divariasikan beraneka macam mutiara laut asli Lombok. ${ }^{6}$

Secara umum, bila memperhatikan seluk beluk keberadaan Pondok Pesantren Al-Raisiyah, maka dapat ditemukan beberapa keunggulan dan keunikan di dalamnya, antara lain: (1) pengelolaan Pondok lebih mengedepankan aspek-aspek kekeluargaan, di mana tenaga pendidik dan kependidikannya berasal dari kalangan internal keluarga, dan warga masyarakat sekitar pondok, serta memprioritaskan para alumni yang memiliki kompetensi; (2) menyelenggarakan pembelajaran yang lebih mendalam mengenai ilmu gramatikal bahasa Arab (ilmu nahwu) dan bahkan menjadikannya sebagai ciri khas Pondok Pesantren Al-Raisiyah; (3) aspek kurikulum lebih menekankan pemberian materi agama, terutama nahwu sebagai bentuk konsep KTSP pondok; (4) dari aspek sosial masyarakat, Pondok Pesantren Al-Raisiyah tumbuh dan berkembang dalam masyarakat Sekarbela yang mayoritas pengrajin emas dan mutiara Lombok yang cukup terkenal, di mana umumnya masyarakat bisnis memiliki kepedulian yang rendah di bidang pendidikan, (5) para santri diberikan keterampilan/kerajinan membuat perhiasan emas dan mutiara dengan melibatkan usaha masyarakat sebagai tempat magangnya sehingga menjadikan Pondok Pesantren Al-Raisiyah semakin berbeda dengan pondok-pondok yang lain pada umumnya; (6) mempertahankan sarana prasarana asrama bagi santri berupa rumah panggung dari anyaman bambu sebagai simbol tradisional disamping asrama santri yang bersifat permanen dari beton. Selain itu fasilitas ruangan juga masih mempertahankan penggunaan bale tajuk (bahasa Sasak Sekarbela, semacam aula) khususnya untuk pengajian-pengajian kitab yang dilakukan secara halaqah (duduk bersila).

Selain keunikan dan keunggulan di atas, kekhasan pola penerapan manajemen di Pondok Pesantren Al-Raisiyah sangat menarik untuk dikaji lebih mendalam lagi. Perlunya penerapan

${ }^{6}$ Iskandar, Mengenal Sekarbela Lebih Dekat (Yogyakarta: Mahkota Kata, 2011), h 1-22. 
manajemen dengan pola yang tepat dan efektif didorong oleh suatu kenyataan bahwa perkembangan dunia pendidikan dewasa ini semakin kompetitif. Selain itu tuntutan pelayanan pendidikan yang sesuai dengan standar pelayanan minimal pendidikan mengharuskan lembaga pendidikan seperti pondok pesantren harus berbenah. Dengan demikian, manajemen yang handal merupakan sesuatu yang tidak boleh tidak ada dalam pengelolaan pondok pesantren. Penerapan aspek-aspek manajemen pendidikan di pondok pesantren ini tentunya mencakup semua aspek baik kurikulum, pendidik dan tenaga kependidikan, peserta didik, sarana dan prasarana, pembiayaan dan hubungan masyarakat.

\section{Pola Manajemen Kurikulum Pondok Pesantren Al- Raisiyah Sekarbela}

Sebagai lembaga pendidikan yang memroses santri menjadi anak manusia yang bermanfaat dalam kehidupan duniawi dan ukhrawinya, maka pesantren dalam konteks pencapaian tujuan pendidikannya tidak bisa dipisahkan dengan kurikulum yang didesainnya. Oleh karena itu, bukan sesuatu yang naif bila dipandang perlu adanya manajemen kurikulum pesantren yang handal dan mumpuni sekaligus dapat mengantisipasi perkembangan ilmu dan teknologi dewasa ini. Berbicara tentang manajemen kurikulum, dalam konteks penelitian ini lebih menekankan pada pola penerapannya di lapangan yang setidaknya dapat diklasifikasi menjadi empat aspek, yaitu perencanaan kurikulum, organisasi kurikulum, pelaksanaan kurikulum dan pengawasan atau evaluasi kurikulum.

Di Pondok Pesantren Al-Raisiyah Sekarbela berlaku 2 jenis kurikulum, yaitu: Kurikulum Kementerian Agama, yaitu Kurikulum Tingkat Satuan Pendidikan (KTSP) sesuai dengan jenjang pendidikan, dan Kurikulum Takhassus (khusus) sebagai kurikulum khas Pondok Pesantren Al-Raisiyah. Di sini terlihat bahwa pengembangan kurikulum di Ponpes Al-Raisiyah memadukan antara KTSP yang bersifat umum (berisi mata pelajaran formal) dengan Kurikulum Takhassus (berisi pembelajaran Kitab Kuning) sehingga menghasilkan suatu bentuk KTSP Pondok Pesantren Al-Raisiyah dengan proporsi 
lebih banyak justru diberikan kepada Kurikulum Takhassus. Hal ini menjadikan kurikulum Ponpes Al-Raisiyah tergolong cukup unik. Seperti apa yang telah dijabarkan oleh Rohiat bahwa secara praktis konsep kurikulum yang diterapkan di sekolah-sekolah yaitu KTSP. KTSP atau kurikulum 2006 berisi seperangkat rencana dan pengaturan tentang program pendidikan yang dibakukan untuk mencapai tujuan nasional dan cara pencapaiannya disesuaikan dengan keadaan dan kemampuan daerah dan satuan pendidikan (pondok pesantren). ${ }^{7}$

Adapun model evaluasi yang dilakukan di Pondok Pesantren Al-Raisiyah pada dasarnya sama dengan madrasah-madrasah yang lain pada umumnya, yaitu evaluasi harian, tengah semester dan akhir semester serta dilaksanakan dengan jadwal yang telah ditentukan. Kegiatan evaluasi dilakukan dalam rangka untuk mengetahui sejauhmana penguasaan santri terhadap materi pelajaran yang diberikan, dan juga untuk memberikan predikat kenaikan kelas atau tingkat kepada jenjang yang lebih tinggi. Namun dalam kegiatan pengajian sedikit ada perbedaan, terutama pada pengajian-pengajian kitab di mana evaluasi dilakukan dengan menghafal, dan memahami isi kandungan kitab, dan ini dilakukan secara spontanitas untuk kenaikan atau kepindahan kepada materi kitab yang lain, jadi bukan untuk kenaikan kelas. Waktu evaluasipun tidak terikat dengan jadwal dan waktu yang ketat.

Berdasarkan kondisi tersebut di atas, terlihat bahwa manajemen kurikulum telah berjalan dengan baik meskipun belum benar-benar maksimal. Hal ini dibuktikan dengan sudah tersusunnya program-program kurikulum (pembelajaran), disusunnya administrasi pembelajaran berupa silabus dan RPP oleh para guru, dan telah dituangkannya uraian tugas-tugas mengajar guru dalam bentuk jadwal pelajaran beserta tugas-tugas tambahan lainnya baik bagi guru maupun tenaga kependidikan lainnya serta adanya kegiatan evaluasi pembelajaran untuk mengukur tingkat daya serap siswa yang dilaksanakan secara rutin dan berkesinambungan.

${ }^{7}$ Asep Sudarsyah dan Diding Nurdin, Manajemen Pendidikan, (Bandung: Alfabeta 2004), 96. 
Ini menunjukkan bahwa para kepala madrasah yang berada di lingkup Pondok Pesantren Al-Raisiyah telah memahami dengan baik arti penting manajemen kurikulum di suatu lembaga pendidikan sehingga senantiasa berupaya untuk memanfaatkan segenap potensi di madrasah untuk mensukseskan pelaksanaan kurikulum tersebut, baik kurikulum formal maupun kurikulum takhassus. Hal ini sejalan dengan pernyataan Iskandar yang mengingatkan bahwa masalah kurikulum di sekolah/madrasah adalah hal yang paling penting sehingga kepala sekolah/madrasah sebagai manajer pendidikan, diharapkan mampu mengoptimalkan potensi sekolah dalam proses mencapai tujuan pendidikan, termasuk bagaimana mensukseskan implementasi kurikulum yang dapat dicapai dengan melaksanakan fungsi-fungsi manajemen, seperti perencanaan, pengorganisasian, penggerakan (kepemimpinan, motivasi, komunikasi), dan pengendalian. ${ }^{8}$

Catatan penting dalam pelaksanaan manajemen kurikulum di Pondok Pesantren Al-Raisiyah adalah masih adanya kekeliruan dalam pola pikir pengurus pondok yang mengatakan bahwa kurikulum formal, KTSP, merupakan kurikulum siap pakai yang telah disiapkan oleh pemerintah-dalam hal ini Kementerian Agama-dan madrasah hanya bertugas melaksanakan saja. Akibat kesalahan pola pikir ini, maka terdapat perbedaan perlakuan terhadap kurikulum formal dengan kurikulum takhassus. Sebagaimana diketahui bahwa kurikulum takhassus memiliki tim khusus yang bertugas menyusun dan mengembangkannya, sedangkan KTSP sebagai kurikulum formal di Pondok Pesantren Al-Raisiyah disusun tanpa menggunakan tim tertentu. Padahal idealnya, KTSP yang merupakan seperangkat bahan-bahan pembelajaran yang akan diberikan kepada peserta didik harus disusun secara bersamasama oleh seluruh stakeholder pendidikan yang ada di tingkat satuan pendidikan (baik sekolah maupun madrasah) dan berorientasi pada: (1) hasil dan dampak yang diharapkan muncul pada diri siswa melalui serangkaian pengalaman belajar yang bermakna, dan (2) keberagaman yang dapat diwujudkan sesuai

8Iskandar H., Pengelolaan Kurikulum di Tingkat Sekolah (Jakarta: Depdiknas, 2003), 21. 
kebutuhan siswa. ${ }^{9}$ KTSP sebagai kurikulum pendidikan formal semestinya lebih mendapatkan perhatian mengingat legalitas pendidikan peserta didik diatur dalam kurikulum tersebut. kurikulum takhassus meskipun bukan kurikulum formal tetap harus diformulasikan dengan baik mengingat kurikulum ini merupakan ciri khas Pondok Pesantren Al-Raisiyah sekaligus nilai jual kepada masyarakat.

Jadi, jika dikaji lagi secara lebih mendalam terlihat bahwa pola manajemen kurikulum di Pondok Pesantren Al-Raisiyah, pada hakikatnya adalah kurikulum perpaduan (KTSP dengan Takhassus) yang menghasilkan bentuk kurikulum baru, yaitu KTSP Pondok. Pengembangan KTSP pondok ini secara teoretis sangat dimungkinkan karena berdasarkan teori yang ada maka dapat diketahui bahwa penyusunan KTSP di suatu lembaga pendidikan atau satuan pendidikan disesuaikan dengan kondisi masyarakat sekitar dan potensi lokal satuan pendidikan yang bersangkutan. ${ }^{10}$

\section{Pola Manajemen Pendidik dan Tenaga Kependidikan (PTK) Pondok Pesantren Al-Raisiyah Sekarbela}

Manajemen sumber daya manusia atau dalam lembaga pendidikan menjadi manajemen pendidik dan tenaga kependidikan, merupakan bagian dari manajemen organisasi yang memfokuskan pada pengelolaan sumber daya manusia. Pengembangan sumber daya manusia dibagi dalam beberapa area kerja, yaitu desain organisasi, pengembangan organisasi, perencanaan dan pengembangan karir pegawai, perencanaan sumber daya manusia, sistem kinerja pegawai, kompensasi dan gaji, serta kearsipan pegawai. Perlu dipahami juga oleh suatu organisasi bahwa pilar utama dalam membangun organisasi yang berwawasan global adalah kemampuan setiap individu yang tergabung dalam organisasi. Satu pertanyaan kritis muncul karakteristik individu seperti apa yang dibutuhkan oleh suatu lembaga dan bagaimana manajemen pengelolaannya.

${ }^{9}$ Ibid., 13.

${ }^{10}$ Asep Sudarsyah dan Diding Nurdin, Manajemen Pendidikan (Bandung: Alfabeta 2004), 96. 
Karakteristik sumber daya manusia (pendidik dan tenaga kependidikan) yang diperlukan saat ini adalah mereka yang mempunyai integritas, inisiatif, kecerdasan, keterampilan sosial, penuh daya dalam bertindak dan penemuan baru, imajinasi dan kreatif, keluwesan, antusiasme dan mempunyai daya juang (kecerdasan adversity/kemampuan mengubah hambatan menjadi peluang), mempunyai pandangan ke depan dan mendunia. ${ }^{11}$

Penerapan manajemen pendidik dan tenaga kependidikan di Pondok Pesantren Al-Raisiyah cenderung masih menerapkan pola tertutup di mana perekrutan pendidik maupun tenaga kependidikan dilaksanakan secara diam-diam atau tanpa publikasi dan hanya diprioritaskan bagi kalangan tertentu di sekitar lingkungan pondok pesantren. Hal ini dibuktikan dengan adanya pemisahan antara penerimaan guru/pegawai dari kalangan dalam pondok dan luar pondok. Kondisi tersebut tentunya kurang tepat karena akan mempersempit peluang lembaga untuk memperoleh tenaga pendidik maupun tenaga kependidikan yang benar-benar handal, meskipun dalam rekrutmen tersebut telah mengacu kepada karakteristikkarakteristik yang ditentukan pondok, seperti profesionalisme, kejujuran, dan keikhlasan.

Hal ini tentunya berlawanan dengan konsep manajemen PTK yang dijelaskan oleh Herawan dan Hartini, bahwa perencanaan PTK adalah pengembangan dan strategi yang komprehensif guna memenuhi kebutuhan organisasi di masa depan. Kegiatan perencanaan PTK yang komprehensif ini diperlukan untuk menjamin agar jumlah maupun tipe personil yang diperlukan dapat terpenuhi sesuai dengan tempat di mana mereka akan bekerja dengan memenuhi prinsip the right man on the right place on the right job. Karena terkait langsung dengan perencanaan organisasi ke depan, maka fungsi ini dipandang sangat penting dalam rangka mencapai tujuan organisasi di masa yang akan datang. ${ }^{12}$

${ }^{11}$ Imma Helianti Kusuma, Manajemen Pendidikan di Era Reformasi (Jakarta: Jurnal Pendidikan Penabur, 2006), 82.

${ }^{12}$ Endang Hermawan dan Nani Hartini, Manajemen Pendidikan (Bandung: Alfabeta, 2009), 229-51. 
Selain itu, pola manajemen PTK yang terkesan tertutup dalam pengelolaan pendidik dan tenaga kependidikan di Pondok Pesantren Al-Raisiyah Sekarbela, secara tidak langsung juga telah menutup pengembangan karir (career development) guru/pegawai. Career development perlu diciptakan oleh lembaga agar dapat memotivasi setiap individu yang terlibat. ${ }^{13}$ Setiap individu tahu jelas persyaratan yang harus dipenuhi untuk menduduki satu jabatan atau tingkatan tertentu. Jelas di sini dapat menghindari unsur subyektivitas. Career development dapat menjadi satu nilai positif ketika pada setiap level di dalamnya jelas alat ukurnya. "Pengendalian posisi" dapat menjadi partner dalam penerapan career development. Karena dalam pengendalian posisi ada aturan untuk kapan dipromosikan, berapa lama di posisi tersebut, kapan berhenti, individu tersebut direncanakan untuk posisi apa dan sebagainya. Kondisi demikian akan memicu setiap individu untuk berprestasi sesuai dengan harapan individu dan lembaga.

Di samping kekurangan di atas, ada pula pola pengembangan pendidik dan tenaga kependidikan yang sudah berjalan dengan baik dan perlu dikembangkan terus, yaitu pola pembinaan berkesinambungan melalui kegiatan pengajian dan workshop peningkatan mutu, disamping itu lembaga juga perlu mempersiapkan adanya masa orientasi agar guru/pegawai mampu berkembang dan berjuang sesuai yang diharapkan lembaga. Masa orientasi ini perlu didesain sebaik mungkin karena merupakan masa transisi. Kegiatan pada masa orientasi terbatas pada waktu tertentu, dan dapat berupa pelatihan atau kegiatan apa saja yang wajib diikuti oleh setiap individu untuk memenuhi standar yang diharapkan. Selanjutnya masa orientasi ini dapat diteruskan dengan "masa pemantapan" dengan pola yang sama dengan orientasi hanya kadar kompetensi yang dituntut berbeda.

\section{Pola Manajemen Sarana dan Prasarana Pondok Pesantren Al-Raisiyah Sekarbela}

Pada hakikatnya manajemen sarana dan prasarana pendidikan di sekolah atau madrasah merupakan proses pendayagunaan semua sarana dan prasarana yang dimiliki

${ }^{13}$ Ibid., 82. 
sekolah. Manajemen sarana dan prasarana pendidikan merupakan seluruh rangkaian proses kegiatan yang direncanakan dan diusahakan secara sengaja dan bersungguh-sungguh serta pembinaan secara kontinu terhadap benda-benda pendidikan, agar senantiasa selalu dalam keadaan siap pakai (ready to use) untuk proses pembelajaran sehingga proses belajar mengajar semakin efektif dan efisien bagi peningkatan mutu pembelajaran dan tercapainya tujuan pendidikan yang telah ditetapkan.

Pola manajemen sarana dan prasarana di Pondok Pesantren Al-Raisiyah meliputi kegiatan perencanaan, pengadaan, penyimpanan, inventarisasi dan pengawasan serta penghapusan sarana dan prasarana. Perencanaan sarana dan prasarana pendidikan merupakan suatu proses menyusun rencana kebutuhan perlengkapan sekolah untuk periode tertentu dan memadukan rencana kebutuhan dengan dana atau anggaran sekolah yang tersedia. Pengadaan adalah kegiatan untuk menghadirkan sarana dan prasarana dalam rangka menunjang pelaksanaan tugas-tugas yang harus dilakukan oleh sekolah/madrasah.

Kegiatan perencanaan sarana dan prasarana yang diterapkan di Pondok Pesantren Al-Raisiyah Sekarbela mengedepankan pola kehati-hatian dan keterbukaan. Kehati-hatian berhubungan erat dengan masalah pembiayaan atau pendanaan. Keterbukaan dikedepankan karena masalah perencanaan sarana prasarana ini bersumber dari masukan dan permintaan guru, pegawai atau bahkan juga siswa. Sifat kehati-hatian ini terlihat dari pola perencanaan yang melibatkan seluruh komponen pondok atau madrasah seperti kepala madrasah, perwakilan guru, bendahara, komite madrasah dan pimpinan pondok lainnya. Sejalan dengan itu, Rohiat menjelaskan bahwa perencanaan dan pengadaan sarana prasarana sekolah harus direncanakan dengan hati-hati sehingga semua pengadaannya sesuai dengan kebutuhan dan tetap memerhatikan usulan dari semua komponen sekolah serta disesuaikan dengan keuangan madrasah/sekolah. ${ }^{14}$

Pengadaan sarana dan prasarana madrasah di Pondok Pesantren Al-Raisiyah dilakukan dengan beberapa cara sesuai

${ }^{14}$ Rohiat, Manajemen Sekolah; Teori Dasar dan Praktek (Bandung: Refika Aditama, 2009), 27. 
dengan jenis sarana dan prasarana yang diperlukan, yaitu: (1) pemesanan, untuk barang-barang yang bersifat khusus seperti meja, kursi, pakaian seragam atau yang lainnya, (2) pembuatan, untuk sarana prasarana yang bersifat tetap seperti bangunan, lapangan olahraga, taman dan lain-lainya, serta (3) pembelian langsung, untuk barang-barang yang bersifat habis pakai seperti alat tulis kantor (ATK), barang konsumsi (kopi, gula, kue, dan lain-lain).

Pengadaan sarana dan prasarana pendidikan di Pondok Pesantren Al-Raisiyah tergolong dilaksanakan dengan baik dan teratur karena melibatkan panitia tersendiri yang dibentuk melalui musyawarah untuk mufakat. Panitia yang dibentuk ini selanjutnya bertugas mencari dan mengadakan barang yang dibutuhkan sesuai dengan kesepakatan harga yang telah ditentukan. Seluruh rangkaian tugas panitia pengadaan sarana dan prasarana akan berakhir setelah semua barang yang diadakan siap untuk diserahkan kepada bagian sarana dan prasarana.

Hal penting yang terlihat dalam pengadaan sarana dan prasarana di Pondok Pesantren Al-Raisiyah adalah adanya penyesuaian dengan dana yang dimiliki oleh madrasah. Jika sarana dan prasarana dalam pengadaannya membutuhkan dana yang tidak begitu besar dan dana madrasah masih bisa mencukupinya maka akan segera direalisasikan. Tetapi jika sarana dan prasarana membutuhkan dana yang besar maka pengadaan tersebut ditunda dahulu sampai dana yang dibutuhkan sudah dimiliki madrasah.

Setelah sarana dan prasarana yang diperlukan telah dimiliki oleh madrasah dan diserahkan kepada bagian sarana dan prasarana maka langkah selanjutnya adalah melakukan inventarisasi. Proses inventarisasi sarana dan prasarana ini umumnya dilaksanakan dengan cara melakukan pencatatan ke dalam buku inventaris dan menuliskan kode atau nomor tertentu pada fisik barang.

Kegiatan inventarisasi sarana dan prasarana ini sangat dibutuhkan untuk mengetahui sarana prasarana apa saja yang belum dimiliki dan dibutuhkan oleh warga sekolah sehingga permintaan barang dapat dilakukan dengan maksimal dan cepat diadakan. Inventarisasi sarana dan prasarana yang baik dan 
teratur akan berimbas pada kateraturan pemakaian dan pemanfaatan sarana prasarana oleh semua warga sekolah. Hal ini sejalan dengan pandangan yang disampaikan oleh Ruhiat yang menyampaikan bahwa semua sarana dan prasarana sekolah, seperti perabot, peralatan kantor dan sarana belajar harus selalu dalam keadaan siap pakai sehingga setiap saat diperlukan, selalu tertata, enak dipandang dan tidak cepat rusak. ${ }^{15}$

Fungsi manajemen selanjutnya setelah inventarisasi sarana prasarana adalah fungsi pemakaian dan pemeliharaan. Dalam hal penggunaan atau pemanfaatan sarana prasarana di Pondok Pesantren Al-Raisiyah disesuaikan dengan kebutuhan akan barang tersebut dan sesuai dengan fungsinya, agar dapat diperoleh manfaat dari penggunaan barang tersebut. Peminjaman barang harus sesuai dengan aturan yaitu dicatatkan dalam buku pemakaian barang inventaris yang merupakan tanggung jawab bagian sarana dan prasarana. Jadi dalam penggunaan sarana dan prasarana harus mengikuti prosedur yang telah ditetapkan oleh madrasah. Hal ini dilakukan untuk mencegah pemakaian barang yang berlebihan, penggunaan barang yang tidak sesuai dengan kebutuhan dan tertib administrasi sehingga sarana dan prasarana yang dimiliki madrasah dapat dimanfaatkan dengan baik oleh seluruh warga madrasah. Sedangkan dalam masalah pemeliharaan sarana dan prasarana di Pondok Pesantren Al-Raisiyah Sekarbela dilakukan secara teratur setiap tahun. Pemeliharaan sarana dan prasarana ini terkait dengan kegiatan perbaikan sarana prasarana yang mengalami kerusakan. Keputusan perbaikan sarana prasarana ini selalu mengedepankan kemampuan keuangan madrasah. Idealnya semua sarana dan prasarana sekolah, seperti perabot, peralatan kantor, dan sarana belajar selalu dalam kondisi siap pakai pada setiap saat diperlukan. Dengan sarana dan prasarana sekolah yang selalu dalam kondisi siap pakai itu semua personil sekolah dapat dengan lancar menjalankan tugasnya masingmasing. Dalam rangka itu, tentunya semua sarana prasarana di madrasah itu bukan saja ditata sedemikian rupa melainkan juga dipelihara dengan sebaik-baiknya. Dengan pemeliharaan secara

${ }^{15}$ Ibid., 30. 
teratur semua sarana dan prasarana pendidikan di madrasah selalu enak dipandang, mudah digunakan dan tidak cepat rusak.

Hal unik yang ditemukan dalam penelitian ini terkait dengan penerapan manajemen sarana prasarana adalah kegiatan pengawasan sarana dan prasarana di Pondok Pesantren AlRaisiyah Sekarbela dilaksanakan melalui kegiatan pengecekan dan penghapusan sarana prasarana yang dipandang sudah tidak layak pakai lagi. Kegiatan pengecekan atau penghapusan sarana dan prasarana di Pondok Pesantren Al-Raisiyah tidak mengenal adanya penghapusan. Sarana dan prasarana yang dinilai sudah tidak layak pakai lagi di Pondok Pesantren Al-Raisiyah ternyata masih diupayakan untuk diperbaiki, akibatnya biaya perbaikannya setiap tahun terkadang bertambah besar. Hal ini terjadi karena keterbatasan anggaran untuk pengadaan sarana dan prasarana tersebut. Hanya saja untuk melakukan penghapusan barang tersebut tidak dilakukan. Barang-barang yang sudah tidak layak pakai biasanya dibiarkan atau disimpan di gudang dan tidak dilakukan penghapusan secara fisik maupun administratif.

Hal ini tentunya sedikit bertentangan dengan pendapat Rohiat yang menjelaskan bahwa semua jenis sarana dan prasarana yang tergolong sudah rusak berat, tidak dapat dipakai lagi atau bahkan tergolong barang kuno maka barang-barang tersebut perlu adanya penghapusan karena apabila barang tersebut tetap disimpan maka antara biaya pemeliharaannya dengan pemanfaatannya secara teknis dan ekonomis tidak seimbang dan seandainya kalau diperbaiki biayanya akan lebih besar sehingga lebih baik membeli yang baru. ${ }^{16}$

\section{Pola Manajemen Pembiayaan Pondok Pesantren Al- Raisiyah Sekarbela}

Aspek pembiayaan sangatlah menentukan kelangsungan dari suatu lembaga pendidikan. Dalam merencanakan suatu pembiayaan pendidikan apalagi lembaga pendidikan tersebut merupakan lembaga pendidikan dengan kompleksitas tinggi seperti pondok pesantren, maka pengelolaan keuangan sangat

${ }^{16}$ Ibid., 35. 
menentukan dalam menjamin kelangsungan hidup lembaga pendidikan tersebut. Di sini fungsi manajemen pembiayaan menjadi benar-benar sangat dibutuhkan.

Pola pelaksanaan manajemen pembiayaan di Pondok Pesantren Al-Raisiyah Sekarbela sudah menerapkan pola "manajemen terbuka" dengan memerhatikan penerapan fungsifungsi manajemen pembiayaan dari perencanaan (planning) melalui penyusunan RAPBS, pengorganisasian (organizing) melalui pengalokasian sumber dana, pelaksanaan (directing) melalui penggunaan sumber dana untuk membiayai kegiatan pondok dan pengawasan (controlling) melalui pemeriksaan bukubuku administrasi keuangan dan laporan-laporan keuangan.

Pelaksanaan fungsi-fungsi manajemen pembiayaan ini sejalan dengan pendapat Handoko yang menjelaskan bahwa perencanaan dalam kaitannya dengan sumber dana mencakup tahapan financial planning yang melahirkan istilah budgetting, financial organizing yang mencakup penyiapan anggaran, inventarisir sumber dan menetapkan biaya dan tahap monitoring atau evaluasi jika diperlukan. ${ }^{17}$

Manajemen terbuka yang diterapkan di Pondok Pesantren Al-Raisiyah ini memang sedikit berbeda dengan kebanyakan pondok pesantren yang kental dengan nuansa "paternalistic management" dan umumnya lebih memilih "manajemen tertutup" (close management). Diiakui bahwa para pengelola anggaran di Pondok Pesantren Al-Raisiyah adalah orang-orang yang memiliki hubungan kedekatan dengan pimpinan pondok, akan tetapi telah melalui proses seleksi yang ketat dengan mempertimbangkan kemampuan dan loyalitas.

Pola "manajemen terbuka" ini serasa lebih komplit dengan menyisipkan orientasi nilai menuju akuntabilitas dalam pengelolaan dana dan segala aktivitas di pondok. Orientasi nilai tersebut seperti yang dijabarkan oleh pengurus pondok adalah nilai-nilai yang ditanamkan oleh para pendiri pondok, yakni keterbukaan dan keikhlasan, mengharapkan keridaan Allah Swt.

Temuan penting dari penerapan manajemen pembiayaan di Pondok Pesantren Al-Raisiyah ini adalah belum mempunyai

17T. Hani Handoko, Manajemen Edisi II (Yogyakarta: BPFE, 1990), 79. 
pengelola pondok untuk memaksimalkan potensi ekonomi masyarakat sekitar yang berlatar belakang sebagai pusat kerajinan emas dan mutiara. Akibatnya sumber-sumber keuangan pondok masih sangat terbatas, terutama hanya mengandalkan sumber pembiayaan dari pemerintah yang meskipun bersifat rutin namun secara jumlah masih sangat minim, misalnya BOS, BSM atau bantuan pemerintah lainnya yang tidak tetap.

Keterbatasan kemampuan pondok menggali potensi sumber pembiayaan dari masyarakat ini tentunya bertentangan dengan konsep yang dijabarkan oleh Abubakar bahwa dalam rangka MBS maka kepada sekolah diberikan kewenangan yang besar untuk mencari dan memanfaatkan berbagai sumber dana sesuai dengan kebutuhan masing-masing sekolah karena pada umumnya dunia pendidikan selalu dihadapkan pada masalah keterbatasan dana. ${ }^{18}$ Sumber-sumber pendanaan itu selain yang utama berasal dari pemerintah, yang juga tidak kalah penting adalah menggali sumber-sumber pendanaan yang berasal dari masyarakat karena sumber pendanaan yang terbesar justru berasal dari masyarakat.

Tentunya selain menggali sumber pendanaan dari masyarakat, pondok juga dapat melakukan kegiatan-kegiatan ekonomi produktif untuk menambah sumber pendanaan pondok. Salah satunya adalah dengan memanfaatkan Koperasi Pondok Pesantren (Kopontren). Kehadiran Kopontren di pondok diharapkan dapat menjadi cikal bakal program-program perimbangan biaya yang tentunya harus dikelola secara professional dan sesuai aturan perundang-undangan yang berlaku.

\section{Pola Manajemen Kesiswaan Pondok Pesantren Al-Raisiyah Sekarbela}

Manajemen kesiswaan merupakan pengaturan terhadap peserta didik mulai dari peserta didik tersebut masuk ke madrasah sampai dengan mereka lulus dari madrasah. Konsep manajemen kesiswaan ini didorong oleh suatu kenyataan bahwa peserta didik mempunyai peran yang sangat penting dalam

${ }^{18}$ Abubakar dan Kurniatun, Manajemen Keuangan Pendidikan, dalam Riduan (ed.) Manajemen Pendidikan (Bandung: Alfabeta, 2009), 256. 
kegiatan pembelajaran di suatu lembaga pendidikan. Peserta didik atau siswa merupakan subyek utama yang akan diproses dalam proses pendidikan di sekolah. Sehingga dengan mengingat peran penting dari peserta didik tersebut sekolah harus benarbenar mampu mengelola dan mengatur peserta didik dengan efektif dan efisien.

Pola pelaksanaan manajemen kesiswaan di Pondok Pesantren Al-Raisiyah Sekarbela sudah menerapkan pola "manajemen modern" dengan memerhatikan penerapan fungsifungsi manajemen kesiswaan dari fungsi perencanaan (planning) melalui kegiatan penerimaan peserta didik baru, fungsi pengorganisasian (organizing) melalui pengaturan siswa ke dalam kelas-kelas atau berdasarkan kategori tertentu, fungsi pelaksanaan (directing) melalui pengelolaan kegiatan ekstra kurikuler sebagai wadah pengembangan bakat dan minat siswa serta fungsi pengawasan (controlling) melalui monitoring dan evaluasi kegiatan-kegiatan kesiswaan yang dilakukan oleh kepala madrasah dan urusan kesiswaan atau bahkan juga oleh pimpinan pondok pesantren sendiri.

Pelaksanaan fungsi-fungsi manajemen kesiswaan ini sejalan dengan pendapat Ali Imron yang menjelaskan bahwa perencanaan peserta didik di sebuah lembaga pendidikan merupakan proses pencarian, penentuan dan penyeleksian seseorang untukmenjadi peserta didik di lembaga yang bersangkutan. Umumnya kegiatan perencanaan peserta didik baru mencakup: (a) pembentukan panitia penerimaan peserta didik baru, (b) pembuatan dan pemasangan pengumuman penerimaan peserta didik baru yang dilakukan secara terbuka. ${ }^{19}$ Satu hal yang menjadi kata kunci dari perencanaan peserta didik ini adalah adanya keterbukaan yang optimal dari seluruh pengelola pondok sehingga tidak ada satupun proses penerimaan peserta didik baru yang berlangsung secara tidak wajar.

Manajemen terbuka yang diterapkan di Pondok Pesantren Al-Raisiyah khususnya pada aspek manajemen kesiswaan memang sedikit berbeda dengan aspek-aspek manajemen lainnya seperti manajemen PTK ataupun juga manajemen pembiayaan

${ }^{19}$ Ali Imron, Manajemen Peserta Didik Berbasis Sekolah (Jakarta: Bumi Aksara, 2011), 6. 
yang umumnya lebih memilih "manajemen tertutup" (close management). Meskipun diakui bahwa proses seleksi siswa baru di Pondok Pesantren Al-Raisiyah adalah tidak jauh berbeda dengan proses seleksi di madrasah-madrasah lainnya.

Dalam proses pengorganisasian dan pengawasan peserta didik, Pondok Pesantren Al-Raisiyah lebih condong ke arah pola "manajemen modern" yang ditunjang dengan administrasi kesiswaan yang komplit dan memadai. Selain itu, peran kepala madrasah dan pimpinan pondok seluruh tenaga pendidik dan kependidikan mendukung setiap kegiatan kesiswaan.

Satu hal yang belum maksimal dari pelaksanaan manajemen kesiswaan di Pondok Pesantren Al-Raisiyah adalah belum maksimalnya pengelolaan alumni pondok. Pengelolaan alumni Pondok Pesantren Al-Raisiyah masih belum terorganisir dengan baik dan cenderung masih berjalan apa adanya. Beberapa hal yang penting dilakukan pondok untuk memaksimalkan pengelolaan alumni misalnya: (a) memfasilitasi dan mendorong pembentukan organisasi alumni Pondok Pesantren Al-Raisiyah yang mandiri sehingga dapat menjadi wadah komunikasi dan pengembangan alumni, (b) memperbanyak kegiatan-kegiatan yang melibatkan alumni seperti reuni atau temu alumni, seminar alumni atau kegiatan-kegiatan yang lainnya.

\section{Pola Manajemen Hubungan Masyarakat Pondok Pesantren Al-Raisiyah Sekarbela}

Kegiatan hubungan masyarakat di lingkungan pendidikan pada prinsipnya harus diartikan sebagai rangkaian kegiatan sekolah/madrasah untuk menciptakan hubungan yang harmonis dengan masyarakat atau pihak tertentu di luar sekolah/madrasah agar mendukung ke arah penciptaan efisiensi dan efektifitas pendidikan. Pengertian ini kemudian diterjemahkan sebagai suatu proses komunikasi antara sekolah dengan masyarakat untuk meningkatkan pengertian warga masyarakat akan kebutuhan dan pelaksanaan pendidikan serta mendorong kerjasama untuk memajukan sekolah.

Berkaitan dengan pola manajemen hubungan masyarakat (humas) di Pondok Pesantren Al-Raisiyah Sekarbela cenderung ke arah "pola tradisional" di mana komunikasi madrasah dengan 
orang tua atau masyarakat masih didominasi oleh keberadaan komite madrasah. Selain itu, peran yang diambil oleh komite madrasah juga masih sebatas peran normatif untuk ikut serta dalam kegiatan-kegiatan yang dilaksanakan oleh pondok atau madrasah seperti pengajian, dan kegiatan haul pimpinan pondok. Selain itu peran orang tua/wali juga belum terlihat maksimal terutama dalam memberikan masukan dan mengawasi perkembangan madrasah/pondok secara aktif. Upaya positif pimpinan pondok atau madrasah untuk mengundang tokohtokoh masyarakat guna bersama-sama mengevaluasi pelaksanaan program-program pondok maupun madrasah pada awal tahun pelajaran sudah merupakan suatu nilai lebih dari pelaksanaan manajemen humas di Pondok Pesantren Al-Raisiyah. Semua ini tentunya dimaksudkan untuk lebih mendekatkan madrasah atau pondok dengan masyarakat sehingga program kegiatan madrasah/pondok lebih berorientasi pada kebutuhan masyarakat. Hal ini sesuai dengan pendapat Nuraedi dan Rosalin yang menjelaskan bahwa secara nyata hubungan antara sekolah dengan masyarakat bertujuan untuk: a) meningkatkan kualitas pembelajaran dan pertumbuhan peserta didik, b) memahami kebutuhan-kebutuhan masyarakat yang sekaligus menjadi desakan, c) mengembangkan program-program sekolah ke arah lebih maju dan lebih membumi sehingga dapat dirasakan langsung oleh masyarakat. ${ }^{20}$

Pelaksanaan manajemen humas di Pondok Pesantren AlRaisiyah tergolong unik, terkesan sederhana dan belum maksimal sehingga dibutuhkan adanya suatu terobosan baru untuk membuka "kran" komunikasi dua arah antara pondok dengan masyarakat. Tentu saja dengan satu tujuan utama bahwa humas yang baik akan menciptakan dukungan optimal masyarakat terhadap madrasah atau pondok dan meningkatkan popularitas madrasah sehingga masyarakat benar-benar merasa memiliki madrasah atau pondok pesantren.

${ }^{20}$ Nuraedi dan Rosalin, Kerjasama Sekolah dan Masyarakat, dalam Riduwan (ed.), Manajemen Pendidikan (Bandung: Alfabeta, 2009), 280. 


\section{Catatan Akhir}

Idealisme dari Pondok Pesantren Al-Raisiyah, dan pondok pesantren yang lain pada umumnya, adalah bagaimana melahirkan postur santri yang cerdas kognitifnya sekaligus cerdas spirituilnya. Cita-cita yang demikian menuntut paradigma pendidikan yang balancing muatan kurikulumnya antara kurikulum format KTSP dan kurikulum takhassus agar kualitas output tidak berat sebelah dan ke depannya pihak Pondok Pesantren Al-Raisiyah harus mampu meretas kultur pengembangan keilmuan interconnection and interrelation antara dua kultur keilmuan; ilmu agama (al-ulum al-naqli) yang merupakan wajah lama pesantren yang jenial dan ilmu sekular (al-ulum alaqli). Pada akhirnya wajah pesantren nantinya merupakan pengejawantahan dari adagium slogan yang nyaring terdengar di balik bilik pesantren: al-muhäfazah 'alà al-qadìm al-șalih wa al-akhzu bil jadid al-aslah (menjaga tradisi lama [basis jenial pesantren berupa ilmu-ilmu agama], dan mengambil hal-hal yang baru yang lebih baik [ilmu-ilmu sekular]). Dengan ini, pesantren diharapkan mampu menjawab the world order (tatanan dunia) modern.

Dan untuk menjawab hajat yang dipaparkan di atas, maka Pondok Pesantren Al-Raisiyah harus mau berbenah dan membuka diri dengan memberikan kesempatan kepada wajahwajah segar yang merupakan produk dari dua dunia; tradisionalitas sekaligus modernitas, untuk tampil ke depan. Artinya, proses regenerasi dan estafeta adalah sebuah keharusan yang harus dilakukan oleh Pondok Pesantren Al-Raisiyah untuk menjawab tuntutan dunia pendidikan yang semakin kompleks. Modernitas pesantren (baca: alih kepemimpinan) di atas, harus diimbangi pula independensitas keuangan Pondok Pesantren AlRaisiyah dengan mendirikan badan-badan usaha mikro untuk menghidupkan Pesantren sehingga Al-Raisiyah tidak hanya sekedar menunggu uluran dan kucuran dana dari Pemerintah dan atau dari para donatur. Potensi usaha mikro keuangan sangat mungkin untuk dipikirkan dan dilakukan oleh pihak pengelola Pondok Pesantren Al-Raisiyah mengingat ia berada di tengah-tengah masyarakat pedagang emas dan mutiara yang tingkat kepatuhan dan penghormatannya terhadap tuan guru sangat tinggi. Ini artinya, pihak pengelola Pesantren Al-Raisiyah 
harus aktif membangun komunikasi yang intens. Dengan demikian, Pesantren Al-Raisiyah mampu menghadirkan dirinya dari umat, oleh umat, dan untuk umat. Skema ini, secara tidak langsung telah melibatkan masyarakat dalam pemenuhan sarana dan prasarana pendidikan di madrasah dan tidak hanya mengandalkan bantuan dari pemerintah.

Selain itu, pihak pengelola Pondok Pesantren Al-Raisiyah harus menyusun grand design dan mapping plan yang harus terukur tingkat ketercapaiannya dan atau kegagalannya. Selain itu, pengelola Pondok Pesantren Al-Raisiyah harus menjamin model opened management dalam segala hal, khususnya terkait dengan pengelolaan keuangan, yang merupakan ranah yang paling rawan konflik. Dan di sinilah peran-serta komite madrasah harus dioptimalkan serta difungsikan lebih aktif untuk mengawal semua proses kependidikan dan pembelajaran di madrasah serta memberikan sumbangan pemikiran bagi kemajuan pondok atau madrasah dan tidak terkesan pasif. Pondok Pesantren AlRaisiyah juga harus melakukan pemetaan sebaran alumninya; pekerjaan, profesi, dan lain sebagainya, yang sewaktu-waktu sangat dibutuhkan kontribusinya. Oleh karena itu, pembentukan Forum Alumni Pondok Pesantren Al-Raisiyah menjadi sangat krusial untuk dipertimbangkan keberadaannya. Wa al-Läh a lam bi al-sawāb.

\section{Daftar Pustaka}

Abubakar dan Kurniatun. 2009. "Manajemen Keuangan Pendidikan", dalam Riduan (ed.) Manajemen Pendidikan. Bandung: Alfabeta.

Azra, Azyumardi. 2000. Pendidikan Islam Tradisi dan Modernisasi Menuju Millenium Baru. Jakarta: Logos Wacana Ilmu.

Bloom, Benjamin S. 1981. Taxonomy of Educational Objectives. New York: Longman, Inc.

Dhofier, Zamakhsyari. 2011. Tradisi Pesantren Studi Tentang Pandangan Hidup Kiyai. Jakarta: LP3ES.

Fattah, Nanang. 2001. Landasan Manajemen Pendidikan. Bandung: RR. 
Griffin, Ricky W. 1997. Management. New Delhi: Houghton Miffin Company.

Handoko, T. Hani. 1990. Manajemen Edisi II. Yogyakarta: BPFE. Hermawan, Endang dan Nani Hartini. 2009. Manajemen Pendidikan. Bandung: Alfabeta.

Imron, Ali. 2011. Manajemen Peserta Didik Berbasis Sekolah. Jakarta: Bumi Aksara.

Iskandar H. 2003. Pengelolaan Kurikulum di Tingkat Sekolah. Jakarta: DEPDIKNAS.

Iskandar. 2011. Mengenal Sekarbela Lebih Dekat. Yogyakarta: Mahkota Kata.

Kusuma, Imma Helianti. Manajemen Pendidikan di Era Reformasi. Jakarta: Jurnal Pendidikan Penabur.

Mastuhu. 1994. Dinamika Sistem Pendidikan Pesantren. Jakarta: INIS.

Masyhud, Sulthon. 2005. Manajemen Pondok Pesantren. Jakarta: Diva Pustaka.

Nuraedi dan Rosalin. 2000. "Kerjasama Sekolah dan Masyarakat" dalam Riduwan (ed.), Manajemen Pendidikan. Bandung: Alfabeta, 2009.

Rohiat. 2009. Manajemen Sekolah; Teori Dasar dan Praktek. Bandung: Refika Aditama.

Saridjo, Marwan. dkk. 1979. Sejarah Pondok Pesantren di Indonesia. Jakarta: Dharma Bhakti.

Sudarsyah, Asep dan Diding Nurdin. 2004. Manajemen Pendidikan. Bandung: Alfabeta.

Wahid, Abdurrahman. 1999. Bunga Rampai Pesantren. Jakarta: Dharma Bhakti. 2001. Menggerakekan Tradisi Esai-esai Pesantren. Yogyakarta: LKiS.

Yasmadi, Modernisasi Pesantren Kritik Nurcholis Madjid Terhadap Pesantren Islam Tradisional (Jakarta: Ciputat Press, 2002). 